ARTICLE HISTORY: Received: May 18, 2021 Accepted: July 11, 2021 Published: July 19, 2021

СПЕЦИФИКА РАССЛЕДОВАНИЯ КЛЕВЕТЫ В СЕТИ «ИНТЕРНЕТ»

\author{
Долженко Н.И. \\ канд. юрид. наук, дочент \\ Белгородский государственный национальный \\ исследовательский университет \\ (НИУ «БелГУ») \\ Вочкина Юлия Геннадиевна \\ студентка 5 курса Юридического института \\ НИУ «БелГУ»
}

\title{
SPECIFICITY OF INVESTIGATION OF SLAVERY ON THE INTERNET
}

N.I. Dolzhenko

Cand. legal Sciences, associate professor

Belgorod State National

Research University

$N R U$ «BelSU»

Voshkina Yulia Gennadievna

5 th year student of the Law Institute

$N R U \ll B e l G U »$

\begin{abstract}
Аннотация. В рамках представленной статьи анализируются некоторые проблемные аспекты расследования клеветы в сети «Интернет». Автором критически анализируются наиболее проблемные вопросы и предлагаются эффективные пути их преодоления.

Annotation. Within the framework of the presented article, some problematic aspects of the investigation of libel on the Internet are analyzed. The author critically analyzes the most problematic issues and proposes effective ways to overcome them.
\end{abstract}

Ключевые слова: клевета, интернет, расследование преступлений, оперативно-разыскная деятельность

Keywords: libel, internet, crime investigation, operational-search activity

Клевета - это преступление, предусмотренное ст. 128.1 УК РФ. Ранее единственным способом распространения клеветы были публикации в печатных изданиях, высказывание порочащих сведений в публичных выступлениях и пр. В настоящий же момент данный состав преступления получил новую область распространения - сеть «Интернет». Распространение клеветы в сети «Интернет» является квалифицирующим признаком, и уголовная ответственность за него предусмотрена ч. 2 ст. 128.1 УК РФ [1].

Расследование преступлений в виртуальном пространстве само по себе является достаточно сложным, так как следователи сталкиваются с трудностями при обнаружении следов преступления, поиске виновных лиц и пр. Кроме того, в сети Интернет гораздо проще совершать преступления анонимно, в том числе и публиковать сведения, являющиеся клеветой. Если мы проанализируем ранее существующие редакции Уголовного кодекса РФ, то увидим, что клевета как преступление ранее существовала в УК РФ, однако впоследствии была декриминализирована, и вновь криминализирована в 2012 году. Общественная опасность клеветы заключается в том, что такие сведения могут нанести не только сильный моральный ущерб оклеветанному лицу, но также ущерб его чести и достоинству, а для юридического лица - ущерб деловой репутации. Кроме того, клевета может стать причиной материальных лишений потерпевшего лица. Особенно актуально это для юридических лиц и индивидуальных предпринимателей.

Итак, распространение клеветы в Интернете не встречает на своем пути никаких преград. Любой пользователь может зайти на форум, сайт, страничку в социальной сети или через личные сообщения начать распространять порочащие сведения, не соответствующие реальной действительности. Более продвинутые пользователи пользуются VPN-маршрутизаторами и иным программным обеспечением, которое позволяет скрыть или изменить IP-адрес компьютера, с которого осуществлялось распространение. Это также не обязательно делать с помощью домашней сети: достаточно прийти с ноутбуком в торговый центр или кафе, подключиться к общей сети и опубликовать порочащие сведения. В этом случае задача по поиску виновного лица также значительно усложняется. Если мы проанализируем данные судебной статистики, то увидим, что в 2018 году по ч. 2 ст. 128.1 УК РФ было осуждено 22 человека, в 2019 - 7 человек, в 1 полугодии $2020-9$ человек [11]. Такие статистические данные могут свидетельствовать о двух вещах: или клевета в сети 
«Интернет» как преступление стала осуществляться реже, или же наоборот - преступники научились лучше скрываться от правоохранительных органов.

Итак, если говорить о проблематике расследования клеветы в сети «Интернет», то первая проблема - это поиск виновного лица. Нередко у лиц, которые распространяют порочащие сведения в Интернете, даже нет явно выраженного мотива. Как совершенно верно утверждает, О.С. Ерашова, оно может осуществляться «лицами, ранее не знакомыми с потерпевшими, не имеющими общих интересов» [7, с.108], а это значительно усложняет поиск. Особенно часто с этим приходится сталкиваться публичным людям, хотя и обычные пользователи также могут попасть под удар. Но как следует из анализа судебной практики, зачастую клеветниками являются знакомые потерпевшему люди. В качестве примера приведем приговор Судебного участка № 416 Пресненского судебного района (г. Москва) № 01-0001/416/2017 от 12 апреля 2017 года. Согласно материалам дела, гражданин М.А. Миркушов был осужден по ч. 2 ст. 128 УК РФ за то, что действуя по мотиву личной неприязни, он на сайте Livejournal опубликовал статью «Коррупция в Департаменте кадров МИД России - Лавров в шоке или в теме?», которая содержала порочащие сведения в отношении замдиректора департамента кадров МИД РФ В.С. Шпанкина [4].

Еще одна проблема расследования клеветы в Интернете - это выявление наличия умысла виновного лица. Клевета - это преступление, совершаемое только с прямым умыслом, то есть виновное лицо должно осознавать противоправный характер своих действий, допускало наступление общественно-опасных последствий и желало их наступления. В этой связи, при расследовании уголовных дел, возбужденных по ст. 128.1 УК РФ одной из главных задач становится процесс доказывания у виновного наличия прямого умысла. Кроме того, С.В. Хмелевский обращает внимание на то, что если лицо, распространяющее порочащие сведения, добросовестно заблуждалось относительно правдивости этих сведений, то оно не может быть привлечено к уголовной ответственности [9, с. 33]. В данном случае также возникает вопрос - а как доказать факт наличия добросовестного заблуждения? Например, гражданин Г. был публично обвинен оценочной комиссией в подделке больничного листа, в результате чего с него удержали часть заработной платы. Дознаватель отказал в возбуждении уголовного дела, мотивируя свою позицию тем, что опрошенные члены комиссии заявили, что услышали информацию о подделке больничного листа от других сотрудников, но каких именно - они не помнят [12]. Таким образом, если нет свидетелей, чьи показания подтверждают факт наличия прямого умысла в осуществлении клеветы, до доказать его практически невозможно. Так и в сети «Интернет» - виновное лицо может заявить, что услышало какую-то порочащую информацию от третьих лиц и добросовестно заблуждалось относительно правдивости распространяемых им сведений. Следовательно, рассуждая теоретически, любая клевета в отсутствии свидетелей, может превратиться в «добросовестное заблуждение», а виновный уйдет от ответственности.

О.С. Ерашова, обращает внимание на такую проблему при расследовании клеветы в сети «Интернет» как определение сроков давности привлечения к уголовной ответственности. Эту же проблему в своих работах затрагивает и А.В. Майоров [8, с. 66]. Тема, на наш взгляд, довольно актуальная, так как в процессе работы с литературой мы встречали мнения ученых, которые утверждали, что распространение клеветы в Интернете имеет длящийся характер и момент окончания совершения данного преступления связан с моментом удаления клеветнической информации из общего доступа. Также мы встречали позицию, что момент окончания совершения преступления - момент публикации информации [10, с. 87]. Таким образом, главный вопрос - в какой именно момент оканчивается клевета в сети «Интернет»?

Чтобы ответить на этот вопрос, обратимся к ПП ВС РФ от 27 июня 2013 года № 19 «О применении судами законодательства, регламентирующего основания и порядок освобождения от уголовной ответственности». В соответствии п. 17 «под днем совершения преступления, с которого начинается течение и исчисление сроков давности привлечения к уголовной ответственности, следует понимать день совершения общественно опасного действия (бездействия) независимо от времени наступления последствий» [3]. Это же положение закреплено в ч. 2 ст. 9 УК РФ. Как известно, все длящиеся преступления сконструированы законодателем таким образом, что они являются оконченными с момента совершения преступления вне зависимости от наступления неблагоприятных последствий. Таким образом, так как клевета в сети «Интернет» - это длящееся преступление с формальным составом, то и оконченной она является с момента распространения порочащих сведений. Применительно к клевете в «Интернете» - с момента публикации информации, содержащей клеветнические сведения.

Ч. 1 ст. 78 УК РФ гласит, что лицо освобождается от уголовной ответственности в случае, если с момента совершения преступления прошло два года. Ч. 2 ст. 128.1. УК РФ подразумевает наступление ответственности за преступления небольшой тяжести, то есть если с момента публикации в сети «Интернет» информации, которая по мнению потерпевшего, является клеветой, прошло два и более лет, то привлечь за такое к уголовной ответственности уже не получится. Например, постановлением мирового судьи судебного участка № 148 СанктПетербурга было прекращено уголовное дело и уголовное преследование в отношении гражданина Демьяненко В.Б. Согласно материалам дела, подсудимый в 2014 году опубликовал в сети «Интернет» сведения о том, что потерпевшая Катасонова Г.Р. якобы обокрала его на 392 тыс. рублей. Однако, потерпевшая обратилась в суд 
только в 2017 году, соответственно, установленный законом срок наступления уголовной ответственности за клевету в сети «Интернет» истек [5]. Этим и руководствовался суд, прекращая уголовное преследование.

Таким образом, для того, чтобы привлечь виновное лицо к ответственности, необходимо своевременно обращаться в правоохранительные органы. Связано это не только с тем, что может истечь срок, но и сам преступник может удалить опубликованные им сведения, что в Интернете сделать совсем несложно. Нередко так и получается: факт клеветы имел место быть, репутация потерпевшего подпорчена, он понес моральные и материальные убытки, а доказать наличие состава преступления невозможно, так как виновным были своевременно удалены все следы совершенного им деяния. Кроме того, трудности с обнаружением доказательств, связаны с тем, что у самих потерпевших не всегда есть техническая возможность зафиксировать факт клеветы в сети «Интернет».

Некоторые ученые, например А.В. Бегичев, говорят о том, что самым значимым доказательством по делу о клевете может стать нотариально заверенный протокол осмотра сайта, где были размещены порочащие сведения [6, с. 30]. Такой протокол составляется исключительно нотариусом, возможность составления такого вида документа закреплена в ст. 45.1 Основ законодательства РФ о нотариате [2]. В этом случае, даже после удаления информации из общего доступа, у потерпевшего на руках останется документ, подтверждающий факт наличия клеветы. К сожалению, получить такой протокол в практической деятельности не так просто. Во многом это связано с тем, что нотариусы весьма неохотно берутся за совершение рассматриваемого нотариального действия в силу его нетипичности и определенной сложности фиксирования. Или, например, нотариус соглашается сделать протокол осмотра сайта, но не сразу при обращении гражданина, а через какое-то время, когда у него не будет текущей загруженности. За этот даже короткий промежуток времени, информация из Интернета уже может быть удалена, поэтому своевременность совершения нотариального действия играет важную роль в формировании доказательственной базы. Также особенностью такого протокола является то, что нотариус обеспечивает доказательства только в отношении гражданского или административного дела. Другими словами, протокол обеспечения доказательств нотариусом может стать доказательством в рамках рассмотрения гражданского дела, по обращению потерпевшего с требованием возмещения морального ущерба, а вот в рамках расследования уголовного дела все доказательства собираются следователем или дознавателем в порядке, закрепленном УПК РФ.

На основании вышеизложенного можно сделать вывод, что моментом окончания клеветы в сети «Интернет» является момент публикации информации, содержащей клеветнические сведения. Для того, чтобы привлечь лицо к уголовной ответственности необходимо своевременно обращаться в правоохранительные органы до того, как информация будет удалена из общего доступа без возможности восстановления. Кроме того, считаем, что и правоохранительные органы должны незамедлительно реагировать на такие обращения граждан по причине, опять же, высокой степени риска утраты доказательств.

Список литературы:

1. Уголовный кодекс Российской Федерации от 13.06.1996 № 63-Ф3 (ред. от 30.12.2020) // Российская газета. 1996. № 113.

2. Основы законодательства Российской Федерации о нотариате (утв. ВС РФ 11.02.1993 № 4462-1) (ред. от 30.12.2020) // Российская газета. 1993. № 49.

3. Постановление Пленума Верховного Суда РФ от 27.06.2013 № 19 (ред. от 29.11.2016) «О применении судами законодательства, регламентирующего основания и порядок освобождения от уголовной ответственности» // Российская газета. 2013. № 145.

4. Приговор мирового Судебного участка № 416 Пресненского судебного района (город Москва) по делу № 01-0001/416/2017 от 12.04.2017. URL: https://sudact.ru/magistrate/doc/M0K7RhrQcngf/ (дата обращения: 19.02.2021).

5. Постановление о прекращении уголовного дела и уголовного преследования мирового судьи судебного участка № 148 Санкт-Петербурга по делу № $1-4 / 2017-148$ от 10.02.2017. URL: https://sudact.ru/magistrate/doc/YljsccJ2Vrbv/ (дата обращения: 19.02.2021).

6. Бегичев А.В. Использование протоколов осмотров интернет-сайтов в судебной практике // Вестник Московского университета МВД России. 2018. № 1. С. 28 - 35.

7. Ерашова О.С. Совершение деяния, подразумевающего клевету в сети Интернет. Проблемы доказывания и исчисления срока давности // Закон и право. 2019. № 5. С. $107-110$.

8. Майоров А.В. Клевета как уголовно-наказуемое деяние // Вестник Уральского института экономики, управления и права. 2019. № 10. С. $65-70$.

9. Хмелевский С.В. «Клевета»: проблемы правоприменительной практики // Социально-политические науки. 2018. № 4. С. $32-36$.

10. Ширкин А.А. Совершение деяния, подразумевающего клевету в сети Интернет // Закон и право. 2018. № 6. C. $85-91$. 
11. Отчет о числе осужденных по всем составам преступлений УК РФ за 2017 - 2020 гг. URL: http://www.cdep.ru/index.php?id=79\&item=5460 (дата обращения: 18.02.2021).

12. Что такое добросовестное заблуждение в случае применения ст. 128.1 УK PФ? URL: https://www.9111.ru/questions/14434616/ (дата обращения: 10.03.2021).

\section{References:}

1. The Criminal Code of the Russian Federation of 13.06.1996 № 63-FZ (as amended on 30.12.2020) // Rossiyskaya Gazeta. 1996. № 113.

2. Fundamentals of the legislation of the Russian Federation on notaries (approved by the RF Armed Forces 11.02.1993 № 4462-1) (as amended on 30.12.2020) // Rossiyskaya Gazeta. 1993. No. 49.

3. Resolution of the Plenum of the Supreme Court of the Russian Federation of June 27, 2013 № 19 (as amended on November 29, 2016) «On the application by courts of legislation regulating the grounds and procedure for exemption from criminal liability» // Rossiyskaya Gazeta. 2013. №145.

4. The verdict of the magistrate judicial district № 416 of the Presnensky judicial district (Moscow city) in the case № 01-0001 / 416/2017 of 12.04.2017. URL: https://sudact.ru/magistrate/doc/M0K7RhrQcngf/ (date of access: 19.02.2021).

5. Resolution on the termination of the criminal case and criminal prosecution of the magistrate of the judicial district № 148 of St. Petersburg in the case № 1-4 / 2017-148 of 02/10/2017. URL: https://sudact.ru/magistrate/doc/YljsccJ2Vrbv/ (date of access: 19.02.2021).

6. Begichev A.V. The use of protocols of examinations of Internet sites in judicial practice // Vestnik Moskovskogo universiteta MVD Rossii. 2018. № 1. P. 28 - 35.

7. Erashova O.S. Committing an act of defamation on the Internet. Problems of proving and calculating the statute of limitations // Zakon i pravo. 2019. № 5. P. 107 - 110.

8. Mayorov A.V. Libel as a criminal offense // Vestnik Uralskogo instituta ekonomiki, upravlenia I prava. 2019. № 10. P. $65-70$.

9. Khmelevsky S.V. "Slander": problems of law enforcement practice // Socialno-politicheskie nauki. 2018. № 4. P. $32-36$.

10. Shirkin A.A. Committing an act implying libel on the Internet // Zakon i pravo. 2018. № 6. P. 85 - 91.

11. Report on the number of those convicted for all types of crimes of the Criminal Code of the Russian Federation for 2017 - 2020. URL: http://www.cdep.ru/index.php?id=79\&item=5460 (date of access: 18.02.2021).

12. What is a bona fide error in the case of application of Art. 128.1 of the Criminal Code of the Russian Federation? URL: https://www.9111.ru/questions/14434616/ (date accessed: 03/10/2021). 